\title{
The Genesis and Internal Dynamics of El Salvador's People's Revolutionary Army, I970-1976
}

\author{
ALBERTO MARTÍN ÁLVAREZ and EUDALD CORTINA ORERO*
}

Abstract. Using interviews with former militants and previously unpublished documents, this article traces the genesis and internal dynamics of the Ejército Revolucionario del Pueblo (People's Revolutionary Army, ERP) in El Salvador during the early years of its existence (1970-6). This period was marked by the inability of the ERP to maintain internal coherence or any consensus on revolutionary strategy, which led to a series of splits and internal fights over control of the organisation. The evidence marshalled in this case study sheds new light on the origins of the armed Salvadorean Left and thus contributes to a wider understanding of the processes of formation and internal dynamics of armed left-wing groups that emerged from the I 960 s onwards in Latin America.

Keywords: political violence, El Salvador, insurgency, armed groups, ERP, FMLN

\section{Introduction}

The Ejército Revolucionario del Pueblo (People's Revolutionary Army, ERP) was one of the most important political-military groups to form El Salvador's Frente Farabundo Martí para la Liberación Nacional (Farabundo Martí National Liberation Front, FMLN) in 1980. The ERP's genesis can be traced back to certain social Christian-oriented groups of the university student movement and, to a lesser degree, to the dissent within the youth group of the Partido Comunista Salvadoreño (Communist Party of El Salvador, PCS) in the late 1960 .

Alberto Martín Álvarez is professor at the Instituto de Investigaciones Dr José María Luis Mora, Mexico City. Email: amartin@mora.edu.mx. Eudald Cortina Orero is a $\mathrm{PhD}$ candidate at the Departamento de Historia Contemporánea y de América, Universidad de Santiago de Compostela. Email: eudald.cortina@gmail.com.

* The authors wish to thank the four anonymous reviewers of the JLAS, whose excellent comments have contributed greatly to the final drafting of this article. We also want to express our debt of gratitude to our informants, whose testimonies have made this work possible. 
The main goal of this paper is to examine how the ERP was structured in its early days and thus contribute to an understanding of its internal dynamics during this first stage (1970-6). The ERP's initial features strongly influenced its subsequent course until its demise as a political-military group in 1992, as well as the path largely followed by the groups that sprang up from it and by the Salvadorean revolutionary movement as a whole. The ERP's internal dynamics were initially marked by the group's inability to remain a unified entity, which was manifest in the rifts that took place from I 973 to 1976 . In turn, the division of the ERP ended the contact it had had with the Fuerzas Populares de Liberación Farabundo Martí (Popular Liberation Forces, FPL) since 1973, which had sought to coordinate the actions of both groups. As a result of all the above, the Salvadorean revolutionary movement was split until I 980 , and this made it impossible to develop a unified strategy.

Although the literature on the Salvadorean revolutionary movement is considerable, ${ }^{\mathrm{I}}$ specific knowledge about how the guerrillas were originally assembled - namely, their emergence and development as small clandestine urban organisations - remains insufficient. The same holds true for the internal dynamics of Salvadorean revolutionary groups; to date, there are only scattered data on this stage. In the particular case of the ERP, the history of its founding years has been gathered together, to a certain degree, in the memoirs published by some of its first militants. ${ }^{2}$ By their very nature,

${ }^{1}$ See, among others, Enrique Baloyra Herp, El Salvador en transición (San Salvador: UCA Editores, 1987); Hugh Byrne, El Salvador's Civil War: A Study of Revolution (Boulder, CO: Lynne Rienner, 1996); James Dunkerley, The Long War: Dictatorship and Revolution in El Salvador (London: Verso, I 982); Sara Gordon, Crisis politica y guerra en El Salvador (Mexico City: Siglo XXI, 1989); Ivon Grenier, The Emergence of Insurgency in El Salvador: Ideology and Political Will (Pittsburgh, PA: University of Pittsburgh Press, 1999); Aldo Lauria Santiago and Leigh Binford, Landscapes of Struggle: Politics, Society and Community in El Salvador (Pittsburgh, PA: University of Pittsburgh Press, 2004); Mario Lungo, El Salvador in the Eighties: Counterinsurgency and Revolution (Philadelphia, PA: Temple University Press, 1996); Cynthia McClintock, Revolutionary Movements in Latin America: El Salvador's FMLN and Peru's Shining Path (Washington, DC: United States Institute of Peace Press, 1998); Tommie Sue Montgomery, Revolution in El Salvador: From Civil Strife to Civil Peace (Boulder, CO: Westview Press, I 995); Jenny Pearce, Promised Land: Peasant Rebellion in Chalatenango El Salvador (London: Latin American Bureau, 1985); Timothy WickhamCrowley, Guerrillas and Revolution in Latin America: A Comparative Study of Insurgents and Regimes Since 1956 (Princeton, NJ: Princeton University Press, 1992); and Elisabeth J. Wood, Insurgent Collective Action and Civil War in El Salvador (Cambridge: Cambridge University Press, 2003).

${ }^{2}$ Arquímedes Antonio Cañadas, Sueños y lágrimas de un guerrillero: un testimonio sobre el conflicto armado en El Salvador (San Salvador, 2013); Fermán Cienfuegos, Veredas de audacia (San Salvador: Arcoiris, 1993); Carlos Rico Mira, En silencio tenía que ser (San Salvador: Universidad Francisco Gavidia, 2004); Eduardo Sancho, Crónicas entre los espejos (San Salvador: Universidad Francisco Gavidia, 2002). Some recent works by academics contribute valuable information, although their aim was not to analyse either the ERP's formation process or its internal dynamics. See, for instance, Joaquín M. Chávez, 
however, these materials were written not with the goal of creating a history of the organisation, but rather with the aim of portraying the authors' experiences. Likewise, there is no intent to analyse the ERP's internal dynamics; therefore, references to internal conflicts are often episodic, loosely connected and subjective.

This paper is a contribution to the available knowledge on the ERP's origins and early internal dynamics and thus broadens the evidence on the formation processes of Latin American revolutionary New Left organisations. It draws on in-depth interviews conducted with former ERP militants who came from each of the various collectives that made up the organisation in 1971-2. As far as possible, information from the interviews was triangulated by asking several of the interviewees the same key questions. Other sources were a series of internal ERP documents drafted between I971 and 1976, found at San Salvador's Museo de la Palabra y la Imagen (Museum of Word and Image, MUPI), Fabio Castillo Figueroa's personal archive and the Centro de Información, Documentación y Apoyo a la Investigación (Centre for Information, Documentation and Research Support, CIDAI) of the Universidad Centroamericana (Central American University, UCA). To date, they are unpublished in academic research on the ERP.

\section{El Salvador's Political Context in the Late Ig6os}

The organisational antecedents of the ERP can be found in a short-lived entity, El Grupo (The Group), whose origins can be traced back to the radicalisation process that a significant sector of the Catholic-oriented university student movement went through in the late 1960 s. These radicalised young Catholics, represented mainly by students who were a part of Acción Católica Universitaria Salvadoreña (Salvadorean Catholic University Action, ACUS) and the Movimiento Estudiantil Social Cristiano (Social Christian Student Movement, MESC), gradually began to move away from the idea of social and political reform, which both organisations advocated, until finally opting for a definitive split with electoral politics. This rift occurred due to the evident limits that the authoritarian regime imposed on the participation

'The Pedagogy of Revolution: Popular Intellectuals and the Origins of the Salvadoran Insurgency, 1960-1980', unpubl. PhD diss., New York University, 2010; Dirk Kruijt, Guerrillas: War and Peace in Central America (London: Zed Books, 2008); and Alberto Martín Álvarez, From Revolutionary War to Democratic Revolution: The Farabundo Martí National Liberation Front (FMLN) in El Salvador (Berlin: Berghof Conflict Research, 2010). There is also a recent journalistic work about the birth of the ERP: Geovani Galeas, Héroes bajo sospecha: el lado oscuro de la guerra salvadoreña (San Salvador: Athena, 2013). The author hardly mentions his sources of information, however, so the book's utility as a source for historical knowledge on the Salvadorean revolutionary Left is quite limited. 
of the electoral opposition - embodied in the Partido Demócrata Cristiano (Christian Democratic Party, PDC) - and also, in general, to a democratisation of the political system. To better understand the ERP's genesis, it is necessary to briefly outline El Salvador's political context in the late I96os.

From 1962 onwards, the military regime headed by Lieutenant-Colonel Julio Adalberto Rivera (1962-7) issued a series of modernising measures. The main goal of the regime's relative opening-up was to re-establish the state's support bases, which had been eroded by the economic crisis, the repression of workers' protests in 1960, and the winds of change unleashed by the success of the Cuban revolution. To the domestic pressure caused by the implementing of reforms was added international pressure, in particular that exerted by the Kennedy administration within the Alliance for Progress strategy, which made US aid conditional on the Salvadorean government holding more competitive elections, among other measures. In response to this pressure, the Rivera administration enacted a number of reforms, the most notable being those geared towards providing areas for free expression to various organised social sectors - namely, workers and employees, the educational sector and the Catholic Church. In particular, a new labour code allowed public employees to unionise, gave urban workers the right to strike and provided the means for collective conflict resolution. The Rivera administration also passed a rural minimum wage law in 1965 and promoted housing projects. ${ }^{3}$ In an attempt to broaden the political regime's support bases in rural areas, the government also encouraged the organisation of agrarian cooperatives. Moreover, during this period the state earmarked considerable resources for higher education, which, coupled with demographic changes, resulted in a 602 per cent increase in higher education students from 1965 to $1975 .{ }^{4}$ The University of El Salvador (UES) saw its budget quadruple between 1962 and 1969; its infrastructure grew, and it opened the Santa Ana and San Miguel campuses in 1966 and I 969 respectively. ${ }^{5}$

Different social sectors capitalised on these regime openings to acquire an organisational structure and to legally exert pressure in relation to their demands. Thus, several independent union federations were created between I 965 and 1972, such as the Federación Unitaria Sindical Salvadoreña (Unitary Federation of Salvadorean Unions, FUSS) and the Federación de Sindicatos de Trabajadores de la Industria del Alimento, Vestido, Textil, Similares y Conexos de El Salvador (Trade Union Federation of Food, Garment, Textile and Related Workers of El Salvador, FESTIAVTSCES), as well as several

3 Stephen Webre, José Napoleón Duarte and the Christian Democratic Party in Salvadoran Politics, 1960-1972 (Baton Rouge, LA: Louisiana University Press, 1979), p. 70.

${ }^{4}$ Wickham-Crowley, Guerrillas and Revolution in Latin America, p. 220.

5 The country's first private university, the Jesuit UCA, was created in 1965. 
public employee unions, such as the Asociación Nacional de Educadores Salvadoreños 2 I de Junio (2 I June National Association of Salvadorean Educators, ANDES-2I). Numerous student associations were also created, such as the MESC, mentioned above, and the Asociación de Estudiantes de Secundaria (Secondary Education Students' Association, AES). ${ }^{6}$

In 1963, the Rivera administration implemented a reform to elect Legislative Assembly representatives through a mechanism of proportional representation. It aimed to increase the legitimacy of the political system by giving the opposition controlled spaces of representation, given that they had threatened to boycott the elections if said reform were not implemented.7 This allowed the PDC, then the leading oppositional party, to acquire i 4 seats in the Legislative Assembly and 37 mayoralties, including that of the capital city, San Salvador. ${ }^{8}$ In addition, the Partido de Acción Renovadora (Renewal Action Party, PAR), an old label appropriated by Salvadorean Communist Party militants, gained access to the Assembly, as did the social democratic Movimiento Nacional Revolucionario (National Revolutionary Movement, MNR) at a later date, in 1968 .

Social Christian university students embraced the PDC's electoral progress with enthusiasm. In 1964, MESC activists supported Napoleón Duarte's candidacy for mayor of San Salvador. As mayor, Duarte implemented a social reform project through supporting marginal sectors, the 'grassroots promotion' formulated by the Belgian Jesuit and sociologist Roger Vekemans and to which numerous MESC and ACUS activists personally committed themselves. The dream of revolution in freedom, of a profound transformation of Salvadorean society without it being necessary to go through a phase of bloodshed, seemed possible to the social Christian university students of the time. Their first project was 'a policy of radical change, which is why we adopted the definition of revolution ... the idea of revolution in freedom was sometimes spoken of as a revolution of diversity, of change, of democratisation, of an opening towards the grassroots and, in some cases, of a struggle against bureaucratised or politicised structures'.

Since the mid-1960s, many of these activists had been in contact with the Latin American Catholic Left through the training programmes organised by the Christian Democratic Party in Santiago, Chile. ${ }^{\circ}$ These trips exposed some

${ }^{6}$ For a more in-depth analysis of how the social organisations formed, see Paul D. Almeida, Waves of Protest: Popular Struggle in El Salvador, Ig25-2005 (Minneapolis, MN: University of Minnesota Press, 2008).

7 Webre, José Napoleón Duarte, p. 76.

${ }^{8}$ Webre, José Napoleon Duarte, p. 8I. The PDC was founded in 1960.

9 Interview with Dr Jorge Cáceres Prendes, MESC founding member and former leader of the Federación de Estudiantes Universitarios Social Cristianos (Federation of Social Christian University Students, FRUSC), San Salvador, I 4 Feb. 2012.

${ }^{10}$ Among others, Lil Milagro Ramírez, Rubén Zamora and Jorge Cáceres Prendes took part in these. 
young Salvadorean social Christian leaders to the latest trends in Catholic reformist thought, and this, as well as their interaction with El Salvador's evolving political context, led many student activists to alter their political approach. Their starting point had been a developmentalist and democratising way of thinking centred on the demilitarisation of society. Following this shift, they became more interested in creating spaces for decision-making that diverged from the structures of liberal democracy and facilitated the self-management of various types of collective: unions, field workers' co-ops, and associations. These approaches were in line with the commitment to the poverty-stricken and the downtrodden preached by liberation theologists, the Medellín Conference and the Second Vatican Council. In the Salvadorean political context of the I 960 , this inevitably meant a clash with the traditional power structures; and it was in taking on these practices - namely, autonomous organisation and the fostering of grassroots activism - that social Christian youth came up against the limits of 'bloodless revolution'.

Several events contributed to this - first and foremost, the repression of the major worker and teacher strikes in 1967 and 1968, which were a direct response to the growing inflation and unemployment that affected El Salvador as a result of the lowering of international prices of export agricultural products in 1966 and 1967 . Urban bus drivers (in January 1967), employees at the IUSA factory and ASEO Publico (in February 1967), and ACERO factory workers in the city of Zacatecoluca (in April 1967) went on strike to demand a wage increase. The strike by the ACERO factory turned into a progressive general strike, which was joined by thousands of workers organised by FUSS. FUSS also brought in the Asociación General de Estudiantes Universitarios (General Association of University Students, AGEUS) and even the progovernment Confederación General de Sindicatos (General Confederation of Trade Unions, CGS) in solidarity. In October 1 967 , the first great ANDES- 2 I mobilisation also took place. It lasted throughout 1968 and, thanks to FUSS support, led to an important strike that other sectors progressively joined. As Erik Ching notes, the labour conflict spread beyond the educational sector and unleashed a repressive response from the state. ${ }^{11}$ This included the assassination of two labourers, FUSS members Oscar Gilberto Martínez and Saúl Santiago Contreras, as well as the arrest of hundreds of people, a great number of whom were students affiliated to AGEUS who had joined the strike in solidarity with the educators.

To all this must be added the impact that other elements of the authoritarian political context had on the radicalisation of young university

${ }^{11}$ Erik Ching, 'Local Politics Meets a National Modernisation Project: How Teachers Responded to the 1968 Educational Reform in El Salvador', paper presented at the 2007 Congress of the Latin American Studies Association, Montreal, Canada, 5 Sep. 2007, p. 22. 
students of Christian orientation, such as the banning of the unionisation of rural workers; the persecution of Catholic Church base activists - many of whom were secondary or university students affiliated to ACUS or Juventud Estudiantil Católica (Catholic Student Youth, JEC) - carrying out literacy endeavours among rural workers; ${ }^{12}$ and, last but not least, the regime's refusal to enact any agrarian reform that would really go against the interests of the large agricultural landowners.

Social Christian youth's growing awareness of the narrow boundaries set by the regime for any kind of political participation that could eventually lead to a structural transformation in Salvadorean society was heightened by their disappointment with the role that the Democratic Christian Party could play in this context, given that until then it had seemed to champion their desire for change. The support that the PDC offered the government during El Salvador's war with Honduras in 1969 , along with its drubbing in the municipal elections of 1970 , contributed to a perception that the PDC was in fact playing along with the dictatorship and that the Christian Democratic 'green revolution' reformist strategy was going nowhere. All these factors led some young social Christian activists to conclude that El Salvador's problems could only be solved through armed struggle and socialism.

The example set by some Latin American priests who had joined the guerrillas - most famously, Colombia's Camilo Torres, assassinated in February 1966 - resonated all the more because the conditions for violencefree structural change seemed to be all but absent in El Salvador. And last of all, the international context played a part, in particular the wave of student mobilisations taking place in Europe, Mexico and the United States, of which Salvadorean university students were well aware. Commenting on this, Jorge Cáceres Prendes, one of the Salvadorean social Christian student movement leaders of the late i 960 s, stated: 'I place a lot of importance on this external influence because we are undoubtedly talking about the years in which the world was convulsed, with 1968 and all that, and this affected us a lot.' ${ }^{\prime 3}$

\section{The Birth of 'El Grupo'}

It was in this context that a core of social Christian students created a first collective, called 'El Grupo' by the Salvadorean press, which was oriented towards the practice of armed struggle. It came into being in late 1969 with

${ }^{12}$ Tangible proof of this is presented in Joaquín Villalobos' narrative of the 1969 death threats that he and Rafael Arce Zablah received from the National Guard when they were carrying out literacy activities among rural workers in the municipality of San Juan Opico (La Libertad department) under Father Alfonso Navarro's direction. See Joaquín Villalobos, 'Homenaje a Rafael Arce Zablah', El Diario de Hoy, 28 Sep. 2005.

${ }^{13}$ Interview with Dr Jorge Cáceres Prendes, I4 Feb. 2012. 
young university students who were activists in student organisations linked to the PDC and to Catholic youth organisations. In essence, the birth of the ERP can be traced to this grouping.

One of the key figures in bringing together the first core group was Edgar Alejandro Rivas Mira. A brilliant high-school student and social Christian activist, Rivas Mira was awarded a scholarship to carry out undergraduate studies in chemistry (1967-9) at Tübingen University in West Germany. While there, he came into contact with extreme left-wing student activists, precisely at a time when student protests against the Vietnam War and the 'great coalition' government, and for the democratisation of universities, were reaching their peak. Various testimonies indicate that his interactions with the West German student movement contributed to his political radicalisation. In Germany he made the necessary contacts to enter Czechoslovakia and then Cuba, where he received training in urban guerrilla techniques and made connections with some Latin American guerrilla leaders, in particular with Venezuelan and Guatemalan activists. ${ }^{14}$ On his return to El Salvador in 1969 , Rivas Mira contacted some friends and some MESC student activists with the intention of creating an armed group. To this end, he organised clandestine gatherings at the University of El Salvador during which, alongside discussions about the country's problems, the issue of armed struggle was raised. ${ }^{15}$ Rivas Mira greatly contributed to creating the collective identity of this first grouping by incorporating elements of the political culture of the European New Left, in particular an admiration for Maoist China and a rejection of the Soviet Union and the strategy of communist parties. ${ }^{16}$ Likewise, given the training he had received, he was able to take on a key role in designing the organisational structure and strategy of the fledgling organisation. Also, the fact that he had been in Cuba and had kept in touch with international revolutionaries gave him a strong reputation as someone who possessed the required know-how to captain a revolutionary organisation. He thus earned the admiration of his peers and the legitimacy necessary to become the organisation's almost undisputed leader in its early years. Ana Sonia Medina, who was to become a member of the ERP's national leadership in the late I 970 s, noted of Rivas Mira:

He played a very important role in that the ERP did not become an organisation like the others, dogmatic, book-spouting, that wanted to adapt reality to dogma or to

${ }^{14}$ Interview with anonymous informant, Mexico City, 4 April 20 I I.

is Interview with Eduardo Sancho, former member of the leadership of the ERP and the Fuerzas Armadas de la Resistencia Nacional (Armed Forces of National Resistance, FARN), and of the FMLN's general command, San Salvador, 27 Jan. 201 I.

${ }^{16}$ The ERP went public for the first time wielding a slogan coined by Mao Tse-Tung: 'Power grows out of the barrel of a gun.' ERP, Communiqué No. I, March 1972, MUPI archive, San Salvador, copy in the author's possession. 
theory ... and with all that stuff on Mao Tse-Tung's Chinese thought ... I think that actually he was valuable, not because at the end of the day we understood him or not, but because really he made it possible for us to have a critical and irreverent stance on the Cubans, the Soviets ... Why were we pro-China? If someone had asked us we wouldn't have known it at the time - perhaps it was because Sebastián said so. ${ }^{17}$

Some of the activists contacted by Rivas Mira, such as Eduardo Sancho and Lil Milagro Ramírez, also became important members of the new organisation. Eduardo Sancho and Rivas Mira had been friends since before the latter's departure to West Germany. Sancho and other young people, such as the poet Alfonso Hernández and Carlos Eduardo Rico Mira, cousin to Edgar Alejandro Rivas Mira, had taken part in the student movement's solidarity actions with the 1967 ACERO factory worker strike. This group of young people had been in touch with the Communist Party's Vanguardia de la Juventud Salvadoreña (Salvadorean Youth Vanguard, VJS), were fans of the Cuban Revolution and Che Guevara and, though lacking the necessary knowhow, were thinking about creating an armed group of their own. ${ }^{18}$ Besides attracting those in his literary circle to the armed struggle, ${ }^{19}$ Eduardo Sancho used his contacts with young VJS activists to recruit them into the organisation later on. Lil Milagro Ramírez, at that time a young law student at the UES, met Alejandro Rivas Mira in 1969 through the latter's brother, one of the leaders of the MESC, which was a university youth organisation of the PDC. Ramírez, given her friendship with some of its leaders, had been working with the MESC since i 966 . She became a radical at the university through a process in which her relationship to her peers, and in particular to her MESC colleagues, became more important to her by far than the rest of her social networks. Ramírez was actively involved in the 1968 ANDES-2 I teacher strike and witnessed the repression enforced by the regime, as she wrote to her father when she decided to go underground in late $197 \mathrm{I}$ :

Do you remember we were there during the first ANDES strike? I was one of the most committed to that struggle and my feelings of frustration and impotence began to take shape when I saw the helpless people who were asking for justice and got repression and death in response. I will never forget the mourning when we took the dead bodies

${ }^{17}$ Interview with Ana Sonia Medina, former member of the ERP's political committee, San Salvador, 3 I Jan. 20 I I. 'Sebastián' was Edgar Alejandro Rivas Mira's alias.

${ }_{18}$ Interview with Eduardo Sancho, 27 Jan. 201 I.

19 Sancho belonged to the avant-garde literary collective 'La Masacuata', based in San Vicente. All its members ended up joining one or another of the guerrilla organisations in the early I970s. Sancho joined the ERP together with Alfonso Hernández (alias Arturo or Gonzalo), Luis Felipe Minhero (alias Tomás), Salvador Silis (alias Santiago) and Carlos Eduardo Rico Mira (alias Pancho). The new Salvadorean intellectual Left of the late i96os played an important role in denouncing the military dictatorship, supporting the grassroots movement and promoting armed struggle. 'La Masacuata' is the perfect example of this, though not the only one: a poets' association working together on the publishing of 'The Purple Onion', in which Lil Milagro Ramírez and Alfonso Hernández were involved, is a similar case. 


\section{Alberto Martín Álvarez and Eudald Cortina Orero}

of the workers killed by the Guard to the cemetery ... those were the first times that I reflected on this country and its political conditions ... at that point I thought we had to find another way ... ${ }^{20}$

The rest of El Grupo's first members or collaborators were Christian Democrat activists, many of them leaders within the Juventud Demócrata Cristiana (Christian Democratic Youth, JDC), or were affiliated with Catholic student organisations. Two of them stand out: Carlos Alberto Menjívar, an ACUS member, and Ricardo Sol, a prominent ACUS member and at that time editor of its official publication. He and his wife Luisa Castillo were founding members of the new organisation. At least three other people joined this first group: Ricardo Sol's father-in-law; Fabio Castillo Figueroa, former rector of the University of El Salvador, who had been calling for the creation of an armed organisation since the mid-r96os and had facilitated the military training of some workers and university activists in Cuba; and lastly, a former VJS militant, Salvador Montoya. ${ }^{2 ~}$

Some of El Grupo's activists were responsible for the first and only action undertaken by the organisation: the I97 I kidnapping of a well-known representative of the Salvadorean economic elite, Ernesto Regalado Dueñas, carried out with the aid of Guatemala's Fuerzas Armadas Rebeldes (Rebel Armed Forces, FAR), through one of their cells. ${ }^{22}$ Following this chaotic event, which resulted in the hostage's death, El Grupo fell apart and some of its members went into exile. ${ }^{23}$

\section{The Comandos Organizadores del Pueblo}

The organisation was almost immediately reconstituted as the ERP. ${ }^{24}$ It revolved around Alejandro Rivas Mira, Eduardo Sancho and Lil Milagro Ramírez, the core members who led the new grouping from late i 97 I onwards. They rapidly recruited young Catholic activists from the university student movement. Among them stand out a small collective of students who, since I970-I, had been attempting to create an armed organisation they had

20 'Carta de Lil Milagro Ramírez en la que explica las razones de clandestinizarse', Diario Colatino, 2 I July $2003 . \quad{ }^{21}$ Interview with Eduardo Sancho, 27 Jan. 201 I.

${ }^{22}$ During the early 1970 s the ERP and FAR maintained close cooperation and mutual support. The FAR kept up a strong presence in El Salvador at that time, most prominently at the UES.

${ }^{23}$ Police identified the kidnappers by tapping their phone communications. After arrest warrants were issued, several of them were forced to go underground or leave the country. Several social Christian young people associated with El Grupo who supported the core members were arrested and tortured.

${ }^{24}$ The first time the organisation used this name publicly was in its Communiqué No. I, in which it called for an armed action that was undertaken on 2 March 1972 at San Salvador's Bloom Hospital. 
termed the Comandos Organizadores del Pueblo (People's Organising Commandos, COP).

The relationships between the COP members had been forged while at university, and in some cases dated back to friendships made in Catholic youth organisations such as the JEC. Practically all of them had enrolled at the UES in 1969 and 1970, were 19 or 20 years old - younger than El Grupo's members at the time of its founding - and had become politicised by taking part in a student conflict known at the university as the 'Core Curriculum strike', which had taken place from January to March 1970. This dispute, which stemmed from a group of physics students' discontent with their poor academic results, rapidly escalated into a widespread protest by students from all the faculties against an educational model created during Fabio Castillo Figueroa's term as rector (1963-6). This model was based on the idea of giving all university students a common grounding in the humanities, and thus the curriculum set out a corpus of social and humanistic studies for the first- and second-year undergraduate students. Rafael Velásquez notes that students in these two years 'wanted the university to take a much more leading role on social issues, but also wanted changes to be made to the university's undergraduate curriculum design. So that sparked an exchange of opinions among the young people ... and then it started to move, it was very spontaneous.' 25

Furthermore, the protest questioned the entire UES authority structure, as students demanded that lecturers be fired and that various deans, as well as the rector himself, hand in their resignations. Little more than a week after the conflict had started, the group of students that began to take control of the protest organised the Comité de Representantes de Áreas Comunes (Committee of Core Curriculum Representatives, CRAC), which headed the movement for its duration, and which, among other things, drew up a list of the teaching staff that were to be 'purged' as they were reactionary and hostile to the university students. As Rafael Velásquez notes:

This movement was made up of very rebellious people who started to think that the Committee of Core Curriculum Representatives should play a leading role in that struggle. I mean, it was impressive to see classes democratically elect their leaders, their representatives; it was impressive, all the first- and second-year students became involved in the issue ... but during that period before the strike, for example, communes were created in the Physics Department, in the style of the Paris Commune. They socialised everything - knowledge, assessment and everything that went on there could be called pre-revolutionary. ${ }^{26}$

Despite the evident differences, there are significant similarities between this conflict and the 1967 and May 1968 student strikes in West Berlin and France

${ }^{25}$ Interview with Rafael Velásquez, former member of the ERP'S political committee, San Salvador, 4 Feb. 2010.

${ }^{26}$ Ibid. 


\section{Alberto Martín Álvarez and Eudald Cortina Orero}

respectively. In fact, the Core Curriculum strike was to a large extent a delayed response to that worldwide wave of student mobilisations. Salvadorean students who enrolled at the UES in 1969 and 1970 were heavily influenced by the anti-hierarchical and anti-authoritarian values of the New Left worldwide:

The group of young people who had just enrolled ... were certainly influenced by what had happened for instance in the Cuban Revolution, by Che's actions, by the events of Paris in 1968 , because that year was very rich in international developments that heavily influenced the thinking of the young people of that time, and this also happened with Mexico's Plaza de Tlatelolco ...27

Some key CRAC members were Manuel Rivera, Francisco Jovel, Carlos Arias, Humberto Mendoza, Virginia and Felipe Peña Mendoza, Jorge González, Rafael Arce Zablah, Clara Elisabeth Ramírez, Alejandro Solano, Joaquín Villalobos and Rafael Velásquez. ${ }^{28}$ Many of these leaders had attended private Catholic schools, and as secondary school students had actively taken part in Catholic youth organisations through which they had been influenced by the ideas of liberation theology, and thus become involved in working with marginal communities.

Jorge González, Carlos Solórzano, Rafael Arce Zablah and Joaquín Villalobos were the prime movers of the COP in 1970 and $197 \mathrm{I}$. In this first period, this collective had a stable core of only three or four militants, and other activists sporadically joined them. The latter did so either because of a previously existing friendship (as was the case with Villalobos and Arce Zablah), or because of the relationships they had forged as first-year undergraduates. Most of them had attended private Catholic schools before enrolling at the UES, and were middle or upper middle class. Rafael Arce Zablah was the ideological leader and led the group's political education process. Ana Sonia Medina, a COP member, said of those early days: 'There were very few of us ... we all worked at the university, we were instructors ... in the first cell, there were six of us at first, then three left and three of us remained ... Lito [Rafael Arce Zablah], Joaquín [Villalobos] and Rodrigo [Jorge González], they were the leaders ... others left and a very, very small core remained.'29

This core group began to work together with the ERP at the latter's request, but on the condition that they remain an independent structure: 'The people at the ERP told us they were going to support us, give us solidarity, and we set as a condition that we were not going to become a part of them - and there we were, at Lil Milagro Ramírez's home.'30

By mid-1973, Rivas Mira had requested that the COP members join the ERP once and for all: 'There was a whole discussion during which Sebastián's

${ }^{27}$ Interview with Rafael Velásquez, San Salvador, 6 Oct. 1998.

${ }^{28}$ Interview with Rafael Velásquez, San Salvador, 4 Feb. 20 io.

${ }^{29}$ Interview with Ana Sonia Medina, San Salvador, 3 I Jan. 20 I I.

${ }^{3 \circ}$ Ibid. 
[Alejandro Rivas Mira's] supposedly militarist position shifted, and they proposed integration and not a simple takeover. They proposed that one of us join the leadership ... a vote was cast and Joaquín Villalobos was elected.' ${ }^{31}$

The COP members decided to join the ERP once the latter had officially adopted the strategic approach of 'grassroots resistance' as its political line for the masses. The lack of support in the country for Colonel Benjamín Mejía's March 1972 coup, which sought to make the government respect the electoral results favouring the opposition coalition, made the ERP's leadership reflect on the need to organise and mobilise the people in support of the guerrillas. The grassroots resistance strategy was intended as an answer to this problem. A May I 973 COP document states the previous differences between the ERP's political approach and that of the Commandos, which would have prevented both groups from coming together. From March 1972 onwards, when both groups began a more formal rapprochement, the ERP remained firm on the creation of an armed group as its main goal, while COP members considered it essential to organise the masses at the same time. The other bone of contention lay in decision-making: while the ERP leadership insisted on the need for democratic centralism, the COP was in favour of a more assemblylike form of decision-making that it termed 'horizontal dispersion'. ${ }^{32}$ When the resistance strategy was adopted, the COP's reasons for not fully joining the ERP vanished. From mid- 1973 the COP officially became a part of the latter organisation, but its members were subsumed as a specific structure, so that at least at the beginning, their cells were not dismantled.

\section{The student residence scholarship holders}

A second UES student grouping had been attempting to organise an armed group since mid-1970. They were closely linked to the COP, as they had played a major leading role in the Core Curriculum strike, although they had a dynamic of their own. Most, but not all, of this group's members were scholarship holders living in the UES halls of residence. Key members were Francisco Jovel, Ricardo Adán Díaz Salazar, Gilberto Orellana, Francisco Montes, Carlos Eduardo Rico Mira, Alfonso Hernández and Joaquín Morales Chávez, among others. In the words of Francisco Jovel: 'We started out as a group of maybe seven people who came together when I decided to organise a study circle at the student residence ... we had already created it with the goal

${ }^{31}$ Ibid.

32 'Los Comandos Organizadores del Pueblo', May 1973, MUPI archive, San Salvador, copy in the author's possession. 


\section{Alberto Martín Álvarez and Eudald Cortina Orero}

of training cadres who very gradually were to get involved in creating a revolutionary organisation of a new kind.'33

Both this group and the COP organisers were heavily influenced by the European and Mexican student movement struggles. The former was also characterised by its critical position on the Soviet Union and, in general, its opposition to the strategy of communist parties. In early I97I this collective came into contact with a communist militant who had received military training in Havana: Leonel Lemus Arévalo. At the August 1967 meeting of the Organización Latinoamericana de Solidaridad (Latin American Organisation of Solidarity, OLAS) held in Havana, there was a schism within the ranks of the Salvadorean Communist Party's delegation; some held to a pro-Moscow line, while others supported guerrilla struggle as a fundamental revolutionary strategy. ${ }^{34}$ Roque Dalton and Domingo Mira belonged to this latter group and, together with other communist militants, got commitment to send Salvadorean communists to train in Cuba in order to set up a guerrilla force in El Salvador. Lemus Arévalo was sent to Cuba, and on his return to El Salvador in late 1970 was introduced to Francisco Jovel through former UES rector Fabio Castillo, a friend of Jovel's. Arévalo offered to give these students military training as well as to connect them to El Grupo's surviving activists. This small grouping did not join the ERP; rather, Lemus Arévalo simply committed to coordinating his actions with the ERP, which he began to do in early 1972 .

\section{Dissident communist youth}

Survivors from El Grupo also contacted other high-school and undergraduate student groups throughout 1971. One of them was made up of students from San Salvador's José Celestino Castro Workers' Institute who were associated with the Communist Party through membership in a cell of the latter's youth section, the Unión de Jóvenes Patriotas (Union of Young Patriots, UJP). Eduardo Sancho, who had been collaborating with this organisation in the San Vicente department from the late 1960s, was at first one of the key individuals linking these groups. The Celestino Castro Institute had been established as a PCS initiative to create union organisers and recruit young

${ }^{33}$ Interview with Francisco Jovel, former member of the FMLN's general command and former secretary-general of the Partido Revolucionario de los Trabajadores Centroamericanos (Revolutionary Party of Central American Workers, PRTC), San Salvador, 28 Jan. 20 I I.

${ }^{34}$ See Alberto Martín Álvarez, 'Del partido a la guerrilla: los orígenes de las Fuerzas Populares de Liberación Farabundo Martí (FPL)', in Jorge Juárez Ávila (ed.), Historia y debates sobre el conflicto armado salvadoreño y sus secuelas (San Salvador: Fundación Friedrich Ebert, forthcoming). 
people, and most of its teaching staff were either Communist Party militants or sympathisers:

The Celestino Castro ... was an institute created by the Unitary Federation of Salvadorean Unions [FUSS] ... and other party institutions, by people from the opposition, by ANDES leaders; I mean, the idea was to set up a workers' institute ... all the teaching staff were well known and well thought of, such as Cayetano Carpio's daughter, Mario Medrano, who was ANDES secretary-general, and many other figures, such as Armando Herrera of the Communist Party. ${ }^{35}$

Since the mid-1960s, various sectors within the PCS had been questioning the party's strategy. The victory of the Cuban Revolution, the 1967 outlawing of the PAR, and the 1967-8 repression of the workers' and teachers' strikes had contributed to polarising the various stances within the organisation as to whether it should still take part in elections. In this vein, a significant sector of the organisation's young people began to demand that the PCS adopt armed struggle as a priority strategy. A short time later the party's ambiguous position with regard to the July 1969 El Salvador-Honduras war, which in practice translated into support for Fidel Sánchez Hernández's military government, was the last straw in this process of internal struggle. ${ }^{36}$ Thus, throughout I 970 a stream of UJP militants left the PCS. Some of them joined the party's former secretary-general, Salvador Cayetano Carpio, in the creation of the FPL. ${ }^{37}$ Others, including students of the Celestino Castro Institute, the Centro Nacional de Artes (National Centre of the Arts, CENAR) and the National Institute General Francisco Menéndez (INFRAMEN), as well as some manual labourers, joined the ERP. This group included Dennis Bismarck Julián Belloso, Jorge Meléndez, Mario Vladimir Rogel, José Mario Vigil and Armando Arteaga. They later drew in other secondary and undergraduate student activists such as Sonia Aguiñada Carranza, Lilian del Carmen Letona (who recruited her sister Mercedes) and Arquímedes Antonio Cañadas. This collective had already undertaken some actions before formally joining El Grupo's survivors.

\section{Internal Dynamics $(1972-5)$}

As noted, when the ERP went public in 1972 , it was not yet a unified organisation, but rather a sort of federation of small armed groups that acted in coordination with each other. ${ }^{38}$ Both the COP and the student residence

35 Interview with Sonia Aguiñada Carranza, former member of the ERP's political committee, San Salvador, I I Aug. 2009.

${ }^{36}$ For a detailed narrative of this process, see Martín Álvarez, 'Del partido a la guerrilla'.

${ }^{37}$ Notably, the members of the Frank País cell, which operated at the UES Faculty of Medicine.

${ }^{38}$ By March 1972, as Carlos Eduardo Rico Mira's narrative confirms, the ERP had two operational cells. One was made up of Gilberto Orellana, Leonel Lemus, Carlos Menjívar, 


\section{8}

group maintained separate structures, though they acted in conjunction. The ERP's leadership was at that time made up of Edgar Alejandro Rivas Mira, Eduardo Sancho and Lil Milagro Ramírez, while the COP's leaders were Joaquín Villalobos, Rafael Arce Zablah and Jorge González. Leonel Lemus and Francisco Jovel were the leaders in their group.

Each entity had been organising its own support groups from the start - a structure of collaborators in charge of providing timely logistics, intelligence and support - with varying levels of success. While the COP does not seem to have been very successful, according to the statements of some former militants who stress how small the group's structure was by 1972,39 other groups had a greater capacity to rapidly pull together a wide network around them. This seems to have happened with the student residence collective, which, according to Francisco Jovel, had organised nearly roo people by late I 97 I.$^{40}$

The coming together of different leaderships and parallel structures in the ERP's genesis immediately created organisational problems. The accidental death in April 1972 of Leonel Lemus Arévalo, who was preparing an explosive device in the company of other cell members, ${ }^{41}$ caused the group he was coordinating (Carlos Rico Mira, Francisco Jovel, Armando Sibrián and Manuel Angulo) to become disconnected from the ERP. The accident also forced the ERP to reconstitute its structure in the summer of 1972 . A new column was created, and Eduardo Sancho became responsible for its leadership. Vladimir Rogel and Francisco Jovel became military and political chief respectively, while Alfonso Hernández was in charge of press and propaganda. ${ }^{42}$ From late 1972 onwards, the first divergences in political and strategic approaches began to arise between the different leaderships interacting within ERP. In the words of Francisco Jovel:

The ideological discussion there quickly became very difficult for me because I really insisted that we had to sort out strategic issues, that it wasn't just a question of operating blindly, and there was an enormous tendency, especially on the part of Vladimir Rogel, to espouse a sort of hands-on approach that was militarist and not very reflexive. People also really looked down on those who were interested in the theoretical and intellectual training of guerrillas. ${ }^{43}$

It would seem that this emphasis on armed activities came from the younger militants of the UJP's dissident group, who had less academic and political

Julia Rodríguez and Alfonso Hernández, and the second one of Carlos Rico Mira, Francisco Jovel, Armando Sibrián and Manuel Angulo. See Rico Mira, En silencio tenía que ser, p. 66.

39 Interview with Ana Sonia Medina, San Salvador, 3 I Jan. 201 I.

${ }^{40}$ Interview with Francisco Jovel, San Salvador, 28 Jan. 201 I.

${ }^{41}$ Gilberto Orellana and Carlos Menjívar also died.

${ }^{42}$ Interview with Francisco Jovel, San Salvador, 28 Jan. 201 I.

${ }^{43}$ Ibid. 
background. Sonia Aguiñada stated in interview: 'Those who first developed a military structure were Vladimir, Meléndez and Alejandro Montenegro;44 they were the military chiefs.' 45

As will be seen below, this sector was to later align itself with militants from the COP, and with Alejandro Rivas Mira, in the May 1975 internal clash which fractured the organisation. Throughout 1972 it became evident that there were two distinct perspectives as to what the ERP's strategy should be. One emphasised the need to create a revolutionary strategy in which armed struggle should be a priority, but not the only one. This perspective highlighted the need to build a revolutionary party that could oversee the actions of both the guerrilla force and the grassroots movement, and also create alliances with opposition political parties. The second point of view, on the contrary, stemmed from a distrust of any type of party political organisation, prioritised the creation of a military structure over any other consideration, and saw armed actions in and of themselves as a means of inciting the population to insurgency. These differences were aggravated throughout 1973 until they became untenable. This led to the first rift in the ERP, headed by Francisco Jovel and other militants from the student halls of residence:

We wrote a letter saying our organising body was breaking off the alliance whose purpose had been to unify us ... that although we had striven to find some kind of strategic convergence, we hadn't managed it, that we were sorry to see the ERP was on the path of a militarist deviation, that that wasn't right, that we considered it necessary to forge a revolutionary party, that ... it should head a military effort ... a mass effort outside the law, that we weren't in favour of investing our efforts into creating an election-based party ... but that when the time came we would need to support it if the need arose because that was a form of struggle that couldn't just be dismissed as rubbish ... and that, because of all this, it was best that we held talks, and that we hoped that in future we could end up creating something in common, a solid revolutionary alliance. ${ }^{46}$

Headed by Jovel, others such as Alfonso Hernández (Arturo), Francisco Napoleón Montes (Carlos), Armando Sibrián (Oscar) and Carlos Rico Mira (Pancho) left the ERP and started the preparations necessary for creating a new organisation they called the Organización Revolucionaria de los Trabajadores (Workers' Revolutionary Organisation, ORT), which was the forerunner of the Partido Revolucionario de los Trabajadores Centroamericanos (Revolutionary

44 The recently published testimony by Montenegro (Arquímedes Antonio Cañadas' alias) certainly makes clear that at that time he was a militant with little political training and had no significant influence or participation in the internal debates that were taking place. Something similar can be said about Jorge Meléndez. However, Vladimir Rogel was already powerful in the ERP as chief operating officer (military chief).

45 Interview with Sonia Aguiñada Carranza, San Salvador, I I Aug. 2009.

${ }^{46}$ Interview with Francisco Jovel, San Salvador, 28 Jan. 20 I I. 
Party of Central American Workers, PRTC), founded in 1976. Although at the time they did not know it (given the clandestine nature of their operations), others in the ERP took a very similar stance and were starting to question the organisation's road map.

It seems likely that this internal discussion on strategy started around late 197 I or early 1972 . As mentioned above, the changing national political context, and in particular the February 1972 electoral fraud and the lack of support for Colonel Benjamín Mejía's coup, underscored the lack of connection between the armed organisation and the population. Given that it had no links to social organisations, the ERP had been unable to mobilise people to rise up in support of a progressive coup that could have ousted the military hardliners. This and the armed group's isolation were probably the key elements that triggered soul-searching about strategy within the core of the organisation.

The first attempts at drawing up a strategy aimed at ensuring a strong connection with grassroots organisations date back to late I97 I. ${ }^{47}$ By midI972, the ERP leadership had drafted a document that stated its priorities to be the structuring of the revolutionary vanguard and the encouragement of grassroots resistance in order to start a revolutionary war. ${ }^{48}$ Such a war was to be popular and prolonged and would have two main goals: to defeat the military government, which was referred to as fascist, and to start the march towards socialism. The vanguard party was to lead the infiltration of ERP underground militants into all sorts of social organisations, preferably unions, taking on their collective demands and claims for basic freedoms, and radicalising them by giving them a revolutionary vision. In the document's notion of a prolonged popular war, very similar to the one developed by Vietnam's National Liberation Front, the urban guerrilla force was only the first phase in the creation of a rank-and-file army.

This strategy, however, coexisted with another approach that saw the creation of military committees as a fundamental task during that period. It was based on the premise that the conditions necessary for insurgency were present in the population, and that the armed group's role was to provide the spark to ignite it. To this end, giving organised groups of the population military training was key. Likewise, believing that said insurgency was not far off, it was thought necessary to seek the collaboration of military officers,

47 From an analysis of the existing documents, it seems that from 1971 onwards the ERP attempted to construct a political and military strategy that would allow the guerrilla group to infiltrate social organisations; however, this strategy does not appear to have been thoroughly formulated until mid-1972.

${ }^{48}$ The document was most likely drawn up by Eduardo Sancho, alias Esteban: 'Anteproyecto del Planteamiento Estratégico del E.R.P', Aug. 1972, MUPI archive, copy in the author's possession. 
so that at the right time they would arm the masses and take part in a coup that would overthrow the state and establish a new revolutionary government. ${ }^{49}$

The first, 'Vietnamese' position was espoused by several prominent militants, including Eduardo Sancho, Lil Milagro Ramírez, Armando Arteaga, Julia Rodríguez and Ernesto Jovel Funes. Who exactly represented the second position is not so evident based on the available information, but it seems clear that they were among those who came from the PCS youth wing (Vladimir Rogel, Jorge Meléndez, Mario Vigil) and formed the military leadership of the organisation - one being Alejandro Rivas Mira, who ended up as commanderin-chief. There were probably additional strategic positions within the ERP in those early years, although to date no evidence of such has been found.

Somehow, the resistance strategy was officially adopted by the ERP without there being any real consensus between all the factions on the desirability of that strategy. The ERP's federative organisational make-up was clearly responsible not only for the lack of in-depth debate on this issue within all its sectors, but also for the fact that, to the contrary, this strategy was only adopted by internal groupings as they saw fit. So, the ERP began to recruit new militants for the resistance apparatus throughout 1972. It was organised as a semi-clandestine organisation that would ensure a connection with the grassroots movement and allow armed groups to propagate its revolutionary strategy. ${ }^{50}$ To ensure the bond between the military structure and the mass movement structures, some experienced militants were assigned to set up a linking committee. Some of its members were Eduardo Sancho, Lil Milagro Ramírez, Alfonso Hernández, Armando Arteaga and Ernesto Jovel.5' A fair number of the new militants came from the labour movement and, above all, from the UES, which had undergone a military intervention and had been shut down in July 1972. ERP militants organised a structure named the University Student Resistance (Resistencia Estudiantil Universitaria, REU), which in turn built a legal organisation to operate openly, known as the Frente Universitario Estudiantil Revolucionario Salvador Allende (Salvador Allende University Student Revolutionary Front, FUERSA).52

On a different front, by 1974 the heads of the ERP faction that identified with the resistance strategy (this faction will hereinafter be referred to as the Resistance), and which was made up mainly of members of the liaison unit,

49 Rico Mira, En silencio tenía que ser, p. 66.

so The ERP's leadership consisted from early 1974 of Edgar Alejandro Rivas Mira, Eduardo Sancho, Vladimir Rogel, Jorge Alberto (Lito) Sandoval, Jorge Meléndez, Mario Vigil and Joaquín Villalobos. The latter was the last to join the leadership as part of the agreement reached with the COP. This group represented, at least in theory, each of the sectors that originally made up the ERP.

${ }_{51}$ Interview with Marco Hernández, former ERP member, San Salvador, io April 20 I 2.

52 The Resistance's official emergence is evidenced by the publication, from October 1972 onwards, of Por la Causa Proletaria. 
was engaging in heavy criticism of the organisation's leadership due to its inability to develop a more holistic revolutionary strategy, as well as its refusal to broaden the leadership structures and thus accommodate militants from the popular movement. ${ }^{53}$ It was under these circumstances that Roque Dalton returned to El Salvador and became a political adviser to the national leadership. ${ }^{54}$ Dalton joined the ERP through a cell made up of militants from the Resistance. Given his extensive political grounding, his entry translated into an increase in this faction's capacity for theoretical debate. In 1974, the Resistance promoted the creation of the Frente de Acción Popular Unificada (Unified Popular Action Front, FAPU) that would coordinate all the grassroots organisations that the ERP had infiltrated, as well as those controlled by the FPL and PCS.55 In the eyes of the Resistance militants, the Salvadorean military regime was in a process of escalating fascism, and in order to defeat it, it was necessary to create a broad class alliance, represented by the FAPU. Such an alliance would be formed, alongside the revolutionary forces, by opposition political parties and the progressive sectors of the bourgeoisie and the armed forces. ${ }^{56}$

From late 1974 onwards, the main controversy within the ERP related to the statement by its national leadership that the internal political context guaranteed the conditions necessary for an insurrection. This context was defined by the new electoral fraud that had taken place in the municipal and legislative elections of March that year, and by the boom in popular mobilisations promoted by the FAPU itself. The ERP was to prepare for the coming insurgency by militarising all its structures and bringing all the activists organised by the Resistance structure into military committees. This was not accepted by the Resistance:

Those other elements of the ERP, they wanted to use all these efforts to transform them into a military structure. We did not agree with this, because it meant sacrificing the masses, which was still a work in progress, and we were already convinced our strategy was the right one. So, as this was creating friction ... what we saw was that this was going to destroy our work. And accepting it meant relinquishing power. So that is where it was discussed that the joint chiefs of staff were not ideologically sound, so they had to be removed. ${ }^{57}$

In February 1975, the ERP's national leadership, dominated by the group that was in favour of militarising the organisation, decided they should become the

53 Interview with Marco Hernández, San Salvador, Io April 2012.

54 Roque Dalton joined the ERP in early 1973 in Havana, through an agreement with Edgar Alejandro Rivas Mira, and returned to El Salvador on 24 December that year.

ss By late 1973 and early 1974 there was a rapprochement between the ERP and FPL that led even to the publication of joint communiqués.

${ }^{56}$ Sara Gordon, Crisis politica y guerra en El Salvador (Mexico City: Siglo XXI, 1989).

57 Interview with Marco Hernández, San Salvador, io April 2012. 
joint chiefs of staff, as part of the measures geared towards paving the way for insurgency. This took place precisely at the time that the critical faction namely, the Resistance - was pushing to carry out an inquiry within the organisation's bases on the strategy that was to be followed. As a result, the requirement that the structure be militarised prevented the holding of widespread meetings with activists, and thus it was not possible to stage a debate as had been planned. ${ }^{58}$

Therefore, in the early months of 1975 the internal situation was one of growing polarisation, with an arm that was increasingly connected to social organisations, which guaranteed new recruits and a presence in the popular movement, but was under-represented in the ERP's supreme leadership body. Its only representative was Eduardo Sancho, who was controlled by those in favour of militarising the Resistance's semi-clandestine structures.

It was at this turning point that Armando Arteaga and Roque Dalton were arrested on I3 April i975 on account of a small disciplinary offence. Everything points to the ERP's joint chiefs of staff taking advantage of this excuse to behead the organisation's critical faction, by accusing Arteaga and Dalton of insubordination and of attempting to sabotage the preparations for the insurgency. In view of this situation, and the possibility that they might be assassinated, the Resistance leadership held a meeting on I May and decided to leave the ERP and create a new organisation, the Fuerzas Armadas de la Resistencia Nacional (Armed Forces of National Resistance, FARN). The joint chiefs of staff reacted to this by sentencing the leaders of this movement to death, among them Ernesto Jovel, Lil Milagro Ramírez and Eduardo Sancho, and by attempting to hunt them down. After Arteaga and Dalton were killed on Io May, FPL mediation put an end to what could have resulted in mutual extermination. 59

\section{Consequences}

The consequences of the assassinations and the May 1975 rift were farreaching both for the ERP and for the revolutionary movement as a whole. For the ERP, they signified the beginning of a period of isolation. Both the FPL and the FARN stopped collaborating with this organisation for the rest of the decade, until they were forced by circumstance to admit the ERP into the fledging FMLN in late 1979.

58 A summary of these events was published in Por la Causa Proletaria, 25 (March-April 1976), featured in Por la causa proletaria, a compilation published by the Costa Rican Socialist Party (San Salvador: CIDAI-UCA, undated), pp. I-25, copy in the author's possession.

59 Eduardo Sancho has given an account of the deaths of Arteaga and Dalton: see Sancho, Crónicas entre los espejos, pp. 70-82. 
Dalton's assassination also signified the start of a phase of international isolation for the ERP, given that the possibility of garnering Cuban support had come to an end (albeit temporarily, as it later turned out). Without any conclusive evidence, everything seems to point to the fact that Dalton, trusted by the Cuban government, was placed as an ERP leadership adviser as part of an agreement between Edgar Alejandro Rivas Mira and Havana, as a means of securing Cuban support for the organisation. This also explains why, in late 1975, Rivas Mira and Vladimir Rogel attempted to establish ties with the Chinese Communist Party with the aim of overcoming the international isolation that the ERP had fallen into. In the end the Salvadorean revolutionary movement's disarray prevented it from receiving any meaningful international aid until $1980 .{ }^{60}$

The rifts within the ERP were also responsible, to a certain extent, for the splintering of the guerrilla-controlled grassroots movement. ${ }^{61}$ Since late 1975 a weakened FAPU was under FARN control, while the FPL created its own mass front in July of that year, called the Bloque Popular Revolucionario (Revolutionary Popular Bloc, BPR). For its part, the ERP lost a great deal of its connections to this movement because militants who controlled the Resistance structure left, leaving the ERP isolated from the social organisations that it had influenced or controlled up until that time. This isolation was to a certain extent overcome with the creation of the February 28 Popular Leagues in March 1977.

In addition, the split in the ERP put off the group of progressive military with whom the ERP had been establishing a relationship with the aim of eventually working together towards an insurgency and a coup that would end the military dictatorship. As mentioned above, this call to insurgency was to take place throughout 1975 , but did not come about given the events of May of that year. ${ }^{62}$

After the 1975 crisis, the ERP found itself in a new critical situation in late I 975 and early 1976, around preparations for the Congress held to construct a new partisan structure, the Partido de la Revolución Salvadoreña (Party of the Salvadorean Revolution, PRS). The group that had come from the COP began to manoeuvre to gain control in the organisation, taking up positions in the new national leadership organised for the Congress's activities (May 1975-July

${ }^{60}$ Michael E. Allison and Alberto Martín Alvarez, 'Unity and Disunity in the Frente Farabundo Martí para la Liberación Nacional', Latin American Politics and Society, 53: 4 (2012), pp. 89-1 I 8 .

${ }^{61}$ The FPL's conception of a mass front was distinctly different from that of the ERP and FARN, and was also responsible for this division. On the other hand, ERP and FPL opposition to the presence of political parties in the FAPU would also have accounted for the latter leaving the group of PCS representatives in late 1974.

${ }^{62}$ See Sancho, Crónicas entre los espejos, p. 79. 
1977). At that point Vladimir Rogel, the ERP's chief operations officer (military chief) and a member of the joint chiefs of staff and the national leadership, took a trip to China. Capitalising on his absence, the COP group started moving against him, ${ }^{63}$ and his closest collaborators were removed from positions of responsibility. Thus, 'Melesia or Mireya', ${ }^{64}$ a member of the leadership loyal to Rogel, was suspended from militancy for a two-year period starting in November 1975.65 In December, Rogel and Rivas Mira were also suspended from militancy and removed from leadership. By February 1976, Rogel had been sentenced to death and executed, on charges of being responsible for a 'militarist deviation' in the organisation. ${ }^{66}$ As a result of all this, the faction close to Rogel, the self-proclaimed Divergent Split, led among others by Juan José Yánez and 'Melesia', left the organisation in early 1976. ${ }^{67}$ This critical sector also had strong disagreements with the leadership in terms of the kind of party it was necessary to create, the correct method of liaising with civil society organisations, and the analyses of Salvadorean capitalism that were being expounded by the now dominant sector of the organisation. ${ }^{68}$

In June 1976, Yánez and 'Melesia' were captured by the security forces and under torture gave away the location of several safe houses, which in turn precipitated the July arrests of two leadership members: Ana Guadalupe Martínez and Rodolfo Mariano Jiménez. ${ }^{69}$ This deepened the inner crisis that the organisation was going through. $7^{\circ}$ In August, in the midst of this turmoil,

${ }^{63}$ Dirección Política de la Escisión Divergente del ERP, 'Boletín informativo número I', undated, Fabio Castillo Figueroa's personal archive, San Salvador, copy in the author's possession.

${ }^{64}$ Melesia had joined the organisation through Eduardo Sancho, together with her sister Julia Rodríguez (an alias), and was politically close to the core group that originally came from the PCS youths. In 1976 she was also Vladimir Rogel's romantic partner. Interview with Julia Rodríguez, Mexico City, is May 2013.

65 See 'Prensa Comunista: publicación especial', Oct. 1977, MUPI archive, San Salvador, copy in the author's possession.

${ }^{66}$ According to a document published by the ERP in October 1977, the death sentence was enforced on account of the ERP being 'at war', as it was deemed that the conditions necessary for an insurrection were present, and also on account of the risk that Rogel might head a factional struggle that could put an end to the organisation. See 'Prensa Comunista: publicación especial', Oct. 1977, MUPI archive, San Salvador, copy in the author's possession.

${ }^{67}$ Dirección Política de la Escisión Divergente del ERP, 'Otro vil asesinato de la burocracia troskista del PRS-ERP', March 1976, Fabio Castillo Figueroa’s personal archive, San Salvador, copy in the author's possession.

${ }^{68}$ Dirección Política de la Escisión Divergente del ERP, 'Boletín informativo número I'.

69 See Ana Guadalupe Martínez, Las cárceles clandestinas (San Salvador: UCA, 1996), p. 66.

${ }^{70}$ To all this must be added the September 1975 death of Rafael Arce Zablah, one of the organisation's main ideologues, in a confrontation in Villa de El Carmen (La Unión department). 
Edgar Alejandro Rivas Mira was expelled from the ERP. The crisis came to an end in July 1977, when the sector that originally came from the COP took definitive control of the organisation. ${ }^{71}$

\section{Conclusion}

From I97 I to I974, the ERP operated as a coordinating structure made up of several armed collectives, and not as a hierarchical and unified organisation. Prior to joining the ERP, each of these collectives had created its own leadership and support networks and had developed distinctive ideological and strategic nuances. After the ERP was created, the clandestine conditions under which its militants operated, which required secrecy and militarised structures that favoured obedience over questioning the leadership, made it impossible to open up a broad debate that would lead to a consensual strategy and political line. The case of the ERP - and also of the FPL, which went through a similar rift in 1983 - demonstrates how being forced underground facilitates internal disagreement and splits and prevents internal coherence in armed organisations. As is evidenced in the case of the ERP, the creation of revolutionary Left armed organisations was often the result of 'deluge' processes - that is, organisations came together from different collectives and were united only by the desire to implement a strategy (armed struggle), were based on a certain ideological identification (a current of Marxist thought), and worked together around a vague goal of constructing a socialist project.

The organisational arrangements adopted in these first phases by the Salvadorean guerrillas were later substituted by broader ones that were similar to those of the classic communist parties; this was the case both with the ERP and the creation of the PRS in 1977 , and with the FPL in 1980 , when the Congress was created. This was done in response to the growth of armed organisations and in light of the need to incorporate prominent activists who came from the social movement and who also demanded a place in the decision-making bodies. The case analysed here shows that these changes at a structural level contribute to producing internal crises due to the opposition of the organisation's dominant groups to the opening up and expansion of decision-making mechanisms. In this sense, the tension produced in the ERP by the growth of the organisation is also present in the events and rifts of 1975 and 1976 described above. All of this suggests that the influence of internal organisational changes, and in particular the expansion of decision-making

${ }^{71}$ This group consisted of Joaquín Villalobos, Ana Guadalupe Martínez, Ana Sonia Medina, the Letona sisters, Juan Ramón Medrano, Claudio Armijo, Jorge Meléndez and Jorge González, together with others such as Dennis Bismarck Julián and Arquímedes Antonio Cañadas. 
structures, is still uncharted territory which warrants more intensive research. ${ }^{2}$

As has been discussed, in the case of the ERP the adoption of a federal organisational scheme in which the leadership was made up of representatives of its different factions made it impossible to impose a strategic vision approved by the organisation as a whole. The lack of agreement around the revolutionary strategy, the role of the party and the role of armed struggle versus other modalities of political dispute brought about severe internal differences that were addressed through the various rifts that took place throughout the period under analysis. After late I 974 these differences turned into a power struggle between two main factions, which was settled in May 1975 with the breaking away of an important contingent of militants.

This rupture signified for the ERP the loss of key organisational resources, a disconnection from the social movements, an ending of the rapprochement with the other fledging leftist armed organisation (the FPL), and the organisation's international isolation. Given all the above, this conflict contributed to undermining the legitimacy of the organisation's leadership, in particular that of Edgar Alejandro Rivas Mira, against a collective (the militants who came from the COP) that showed considerable internal cohesion and the manoeuvring capacity to remove him from power. The expulsion of the faction that argued for privileging the development of armed activities in 1976 , and the creation of the PRS-ERP, marked the ending of the organisation's formative years.

It is also important to mention that the genesis of the ERP shows what a key role certain events of the international context played in the development of the revolutionary Left in Latin America. As is well known, the Cuban Revolution produced a change in the cultural repertoire of collective action in Latin America by providing a credible alternative for social transformation and radical policy characterised by the use of armed struggle as a fundamental strategy, and socialism as an alternative form of social organisation. Likewise, Cuba greatly contributed to the creation of organisations in the first phase of the Latin American guerrilla wave in the early 1960s (the foquista groups) through financial support and training. While the influence of Cuba on the Latin American revolutionary Left has been well explored by numerous scholars, ${ }^{73}$ the influence of other international events has barely been researched. The Salvadorean case shows that the wave of student mobilisations

${ }^{72}$ For a first attempt to develop this line of research, see Alberto Martín Álvarez, 'De movimiento de liberación a partido politico: articulación de los fines organizativos en el FMLN salvadoreño (1980-1992)', PhD diss., Universidad Complutense de Madrid, 2004.

${ }^{73}$ See, for instance, Wickham-Crowley, Guerrillas and Revolution in Latin America; Jorge G. Castañeda, La utopia desarmada: intrigas, dilemas y promesa de la izquierda en América Latina (Barcelona: Ariel, I995); and Tanya Harmer, 'Two, Three, Many Revolutions? Cuba 
of the late 1960s in Europe and Mexico, as well as the protests against the Vietnam War, also contributed to the development of a revolutionary political culture within a sector of the Latin American students who, in fact, shared in good measure the same cultural and ideological references as their peers across the Atlantic. ${ }^{74}$

Beyond the events of El Salvador, this work points to the importance of researching the influence of these other international events on the development of the second phase of the guerrilla wave in Latin America, which began in the early I 970 . 75 Thus, this case study suggests the importance of analysing the transnational connections, symbolic and cultural in the first instance, but also financial and material, to better explain the emergence of the organisations of the new revolutionary Left both in Latin America and in Europe, which, despite their differences, can be included in the same wave of activity as the worldwide New Left. ${ }^{6}$ Likewise, the close connection between workers' mobilisations, the student movement and the emergence of the guerrilla movement in El Salvador points to the importance of studying the creation of revolutionary Left armed groups in the continent alongside an analysis of the various protest waves that took place at a domestic level within each country. All of the above is to argue that research on the genesis and internal dynamics of the Salvadorean guerrilla movement has enormous potential to broaden the available knowledge on the emergence, development and demise of new revolutionary Left organisations at a global level.

\section{Spanish and Portuguese abstracts}

Spanish abstract. A través del uso de entrevistas con antiguos militantes y documentos internos inéditos, el artículo reconstruye la génesis y la dinámica interna del Ejército Revolucionario del Pueblo (ERP) de El Salvador durante sus primeros años de existencia (1970-6). Este periodo estuvo marcado por la incapacidad del ERP para mantener cohesión interna o un acuerdo sobre la estrategia revolucionaria, lo que se tradujo a su vez en una serie de cismas y luchas internas por el control de la organización. La evidencia aportada por este caso de estudio, arroja nueva luz sobre los orígenes de las organizaciones de la izquierda armada salvadoreña y contribuye

and the Prospects for Revolutionary Change in Latin America, 1967-1975', Journal of Latin American Studies, 45: I (2013), pp. 61-89.

${ }^{74}$ Albeit with important nuances of their own, such as the key influence of liberation theology and the debates inside the Christian Left.

75 Alberto Martín Álvarez and Eduardo Rey Tristán, 'La oleada revolucionaria latinoamericana contemporánea, 1959-1996: definición, caracterización y algunas claves para su análisis', Naveg@mérica: Revista Electrónica de la Asociación Española de Americanistas, 9 (2012), available at http://revistas.um.es/navegamerica/article/viewFile/I61591/14109I (last checked in July 2014).

${ }^{76}$ Alberto Martín Álvarez and Eduardo Rey Tristán, 'La oleada revolucionaria'. 
asimismo a ampliar el conocimiento disponible sobre los procesos de formación y la dinámica interna de los grupos armados de izquierda surgidos desde los años sesenta en América Latina.

Spanish keywords: violencia política, El Salvador, revolución, grupos armados, ERP, FMLN

Portuguese abstract. Através de entrevistas com antigos militantes e documentos até então não publicados, este artigo traça a gênese e dinâmicas internas do Exército Revolucionário do Povo (ERP) durante os primeiros anos de sua existência (1970-6) em El Salvador. Este período foi marcado pela inabilidade do ERP em manter uma coerência interna ou qualquer consenso em relação à estratégia revolucionária, levando a uma série de divisões e disputas internas pelo controle da organização. As evidências apresentadas neste estudo de caso oferecem uma nova perspectiva sobre as origens da esquerda armada salvadorenha, contribuindo assim para um entendimento ampliado dos processos de formação e dinâmicas internas de grupos armados de esquerda que emergiram a partir dos anos 1960 na América Latina.

Portuguese keywords: violência política, El Salvador, insurgência, grupos armados, ERP, FMLN 